\title{
Hubungan Pengetahuan dan Sikap dengan Tindakan Mahasiswa Program Profesi Dokter Gigi RSGMP Universitas Andalas Terhadap Pengendalian Infeksi
}

\author{
Fitri Utami ${ }^{1}$, Kuswardani Susari Putri ${ }^{2}$ Hidayati $^{1}$
}

${ }^{1}$ Fakultas Kedokteran Gigi Universitas Andalas ${ }^{2}$ Program Studi Psikologi Fakultas Kedokteran Universitas Andalas

\begin{abstract}
Background: In dentistry, level of risk on cross infection can be said very high. This is due to the teeth treatment, the operator may have direct contact with saliva and patient's blood. The implementation of standard precautions is very important in clinical practice because in addition to it must be obeyed, it can avoid the operator and the patient to the cross infection. The purpose: To determine the relationship between knowledge and attitudes with the practices toward infection control of clinical student in dentistry. Methods: This type research analytical observasional by cross sectional study approach. The number of respondents were 61 clinical student of dentistry. The sampling technique by simple random sampling. The data collection done by providing questionnaire concerning knowledge and attitudes to clinical student of dentistry and practice observations toward infection control. Statictical analysis use chi-square. Results: There is significant relationship between the knowledge with the practices toward infection control with $p=0.0005$ and significant relationship between the attitudes with the practices toward infection control with $p=0.023$. Conclusion: High knowledge and positive attitude will be followed by good practice of control infection.
\end{abstract}

Keywords: cross infection, knowledge, attitude, practice, standard precautions

Affiliasi penulis: ${ }^{1}$ Fakultas Kedokteran Gigi Universitas Andalas Korespondensi: Fitri Utami, fitririutami@gmail.com

\section{PENDAHULUAN}

Profesi dokter gigi tidak terlepas dari kemungkinan untuk berkontak secara langsungataupun tidak langsung dengan mikroorganisme dalam darah dan saliva pasien. Penyebaran infeksi dapat terjadi secara inhalasi yaitu melalui proses pernafasan atau secara inokulasi atau melalui transmisi mikroorganisme dari serum dan berbagai substansi lain yang telah terinfeksi. Bukti menunjukkan bahwa tingkat resiko dokter gigi berkaitan langsung dengan kontak terhadap darah dan saliva pasien. Hal ini menyebabkan tindakan dalam praktek dokter gigi menempatkan dokter gigi beresiko tinggi terutama terhadap penyakit menular berbahaya yang disebabkan oleh virus dan bakteri.

Penyakit menular di Indonesia menurut Riset Kesehatan Dasar (RISKESDAS) tahun 2013 diantaranya adalah Tuberkulosis dan Hepatitis. Prevalensi hepatitis tahun 2013 (1,2\%) dua kali lebih tinggi dibanding tahun 2007, selain itu insiden infeksi Human Immunodeficiency Virus (HIV) setiap. tahunnya terus bertambah ${ }^{2}$. Meningkatnya prevalensiorang yang terjangkit penyakit infeksi menular merupakan kondisi yang patut 
diwaspadai khususnya yang berprofesi sebagai dokter gigi, karena dokter gigi merupakan salah satu profesi yang rawan untuk terjadinya kontaminasi silang, sehingga butuh proteksi diri yang lebih maksimal dari dokter gigi untuk melindungi dirinya dari infeksi silang ${ }^{3}$.

Berdasarkan penelitian yang dilakukan Terence Wibowo di Surabaya pada tahun 2016 hanya62,5\% dokter gigi yang menggunakan masker pada saat memeriksa pasien, 43,8\% yang menggunakan kaca mata pelindung, $56,3 \%$ dokter gigi yang melakukan pergantian sarung tangan setiap pasien baru dan $75 \%$ dokter gigi mencuci tangan sebelum dan sesudah perawatan. Masker dan kaca mata pelindung 95\% dapat melindungi dokter gigi dari droplet yang telah terkontaminasi penyakit, mahalnya harga kacamata pelindung dan kurangnya kenyamanan dalam pemakaiannya menyebabkan dokter gigi tidak menggunakannya selama prosedur perawatan ${ }^{4}$.

Goodman dan Solomon mengkaji 13 laporan penularan penyakit menular yang terjadi dalam praktik perawatan gigi antara tahun 1961 dan tahun 1990 diantaranya yaitu satu laporan yang menginformasikan bahwa tuberkulosis paru ditularkan oleh seorang dokter gigi yang terinfeksi TB paru infeksius, sembilan laporan dokter gigi terinfeksi virus hepatitis B dan menularkannya kepada pasien, serta satu laporan yang menginvestigasi dugaan seorang dokter gigi tertular HIV/AIDS ${ }^{5}$.

Berdasarkan World Health Organization (WHO) darah merupakan media paling banyak dalam menularkan infeksi pada petugas kesehatan. Didapatkan kurang lebih tiga juta petugas kesehatan tiap tahunnya terpapar oleh virus yang berasal dari darah, dua juta petugas kesehatan terpapar virus hepatitis $B$, sembilan ratus ribu petugas kesehatan terpapar virus hepatitis $\mathrm{C}$ dan tiga ratus ribu petugas kesehatan terpapar oleh virus $\mathrm{HIV}^{6}$. Center of Disease Control and Prevention (CDC) melaporkan hasil penelitian dari 360 orang tenaga kesehatan kejadian terluka di tempat praktek yaitu $36 \%$ dokter gigi, $34 \%$ ahli bedah mulut, $22 \%$ perawat gigi dan $4 \%$ mahasiswa kedokteran gigi ${ }^{7}$.

Menurut Dental Council (2005) dokter gigi sebagai tenaga kesehatan berperan dalam pencegahan, penatalaksanaan dan perawatan gigi mulut bagi masyarakat yang hidup dengan berbagai penyakit gigi dan mulut. Dokter gigi dinilai tidak etis bila tidak memberikan pelayanan bagi individu karena sematamata individu tersebut menderita AIDS atau HIV, HBV, HCV8. Resiko pekerjaan seperti tertular penyakit menular HIV, HBV, Tuberkulosis disebabkan karena 
kurangnya kesadaran tenaga kesehatan dan rendahnya mutu pelaksanaan sterilisasi yang mengakibatkan tingginya prevalensi penyebaran penyakit infeksi ${ }^{9}$. Faktor-faktor yang berpengaruh terhadap pencegahan penyakit adalah pengetahuan, sikap dan tindakan seseorang terhadap penyakit tersebut. Seseorang yang memiliki pengetahuan yang baik mengenai suatu hal cenderung akan mengambil keputusan yang lebih tepat berkaitan dengan masalah. Pengetahuan dan sikap merupakan respon seseorang terhadap stimulus atau rangsangan yang masih bersifat terselubung dan masih terbatas pada perhatian, persepsi, kesadaran. Sedangkan tindakan merupakan respon terhadap stimulus atau rangsangan yang dapat diamati oleh orang lain ${ }^{10}$. Jadi secara teori pengetahuan seseorang akan mempengaruhi sikap dan sikap tersebut teraplikasi dalam suatu tindakan seseorang.

\section{American Dental Association} (ADA) merekomendasikan bahwa setiap pasien harus dianggap berpotensi menular dan standar precautions harus diterapkan bagi semua pasien. Hal ini bertujuan untuk mengurangi dan mencegah infeksi iatrogenik dan nosokomial. Kontrol infeksi melalui proses sterilisasi merupakan komponen penting dalam proses kontrol infeksi dan keselamatan pasien. Proses strelisasi dan pengaturan area yang tepat dapat menghasilkan proses sterilisasi lebih efisien, meminimalisasi kontaminasi lingkungan, mengurangi kesalahan, menjaga alat tetap steril serta keselamatan pasien dan staf. Dokter gigi dan staf harus melindungi diri dengan mengikuti program imunisasi yang rutin. Standard precaution terdiri dari dua yaitu standar tindakan pencegahan dan transmission based precaution yaitu standar tindakan pencegahan yang di aplikasikan terhadap semua pasien dirancang untuk mereduksi resiko transmisi mikroorganisme dari sumber infeksi yang diketahui dan tidak diketahui seperti darah, cairan tubuh, ekskresi dan sekresi ${ }^{9}$.

Pencegahan ini diterapkan terhadap semua pasien tanpa mempedulikan diagnosis atau status infeksi yang pasti. Kementrian Kesehatan RI pada tahun 2012 telah menerbitkan standar pencegahan dan pengendalian infeksi pelayanan kesehatan gigi dan mulut sebagai pedoman tenaga kesehatan dalam pelaksanaan pencegahan dan pengendalian infeksi yang benar. Ada beberapa kewaspadaan standar dalam praktik kedokteran gigi antara lain kebersihan tangan, penggunaan alat pelindung diri, manajemen limbah dan benda tajam, manajemen lingkungan, penanganan linen, sterilisasi peralatan 
perawatan pasien dan perlindungan kesehatan seperti imunisasi ${ }^{11}$.

Departemen Kesehatan RI 2008 menyatakan bahwa dokter gigi muda sebagai seseorang yang tengah aktif menjalankan pendidikan klinik diberi kesempatan untuk terlibat dalam pelayanan kesehatan dibawah bimbingan dan pengawasan dosen atau supervisior. Dokter gigi muda dalam hal ini sebagai bagian dari tenaga kesehatan wajib menjaga keselamatan dirinya dan orang lain termasuk dalam hal pelaksanaan kontrol infeksi. RSGMP adalah rumah sakit yang menyelenggarakan pelayanan kesehatan gigi dan mulut yang juga digunakan sebagai sarana proses pembelajaran, pendidikan dan penelitian bagi profesi dokter gigi. RSGMP terikat melalui kerjasama dengan fakultas kedokteran gigi ${ }^{12}$.

Berdasarkan hal di atas penulis tertarik mengambali judul tentang hubungan antara pengetahuan dan sikap mahasiswa profesi dokter gigi dengan tindakan pengendalian infeksi yang dilakukan di RSGMP Universitas Andalas.

\section{METODE}

Penelitian ini merupakan penelitian observasi analitik dengan desain potong silang (cross Sectional) yaitu tiap subjek penelitian hanya dilakukan sekali saja dan semua subjek penelitian diamati pada waktu yang sama $^{13}$. Pengambilan sampel dilakukan dengan teknik simple random sampling yaitu pengambilan sampel anggota populasi dilakukan secara acak tanpa memperhatikan strata yang ada dalam populasi itu ${ }^{14}$. Jumlah responden 61 orang mahasiswa program profesi dokter gigi RSGMP Universitas Andalas.

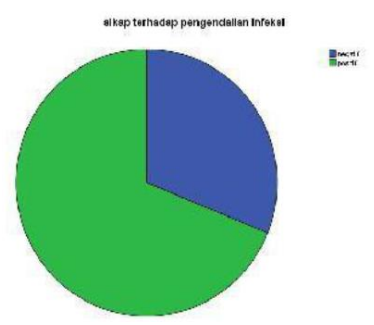

Gambar 1. Distribusi Frekuensi Berdasarkan Pengetahuan Terhadap Pengendalian Infeksi

Dari gambar di atas dapat dilihat bahwa sebanyak $32,8 \%$ responden memiliki pengetahuan yang rendah terhadap pengendalian infeksi dan $67,2 \%$ responden memiliki pengetahuan yang tinggi terhadap pengendalian infeksi. Sikap terhadap pengendalian infeksi mahasiswa program profesi dokter gigi di RSGMP Universitas Andalas terdiri dari kriteria Positif dan Negatif seperti pada tabel berikut ini:

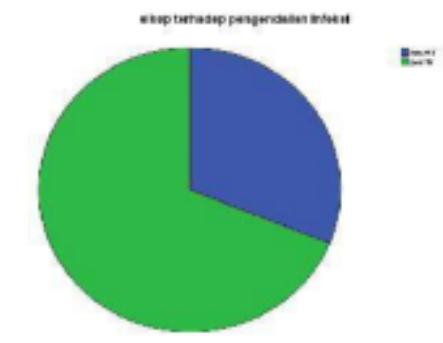

Gambar 2. Distribusi Frekuensi Berdasarkan Sikap Terhadap Pengendalian Infeksi 
Dari gambar di atas dapat dilihat bahwa sebanyak $31,1 \%$ responden memiliki sikap negatif terhadap pengendalian infeksi dan 68,9\% responden memiliki sikap positif terhadap pengendalian infeksi.

Tindakan terhadap pengendalian infeksi mahasiswa program profesi dokter gigi di RSGMP Universitas Andalas terdiri dari kriteria baik dan buruk seperti pada tabel berikut ini:

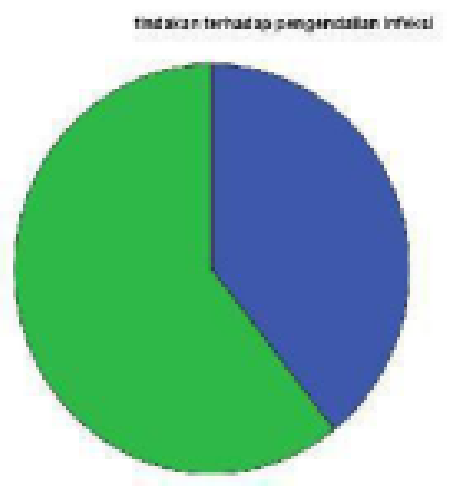

Gambar 3. Distribusi Frekuensi Berdasarkan Tindakan Terhadap Pengendalian Infeksi

Dari gambar di atas dapat dilihat bahwa sebanyak $39,3 \%$ responden memiliki tindakan yang buruk terhadap pengendalian infeksi dan 60,7\% responden memiliki tindakan yang baik terhadap pengendalian infeksi.

Analisa untuk memperlihatkan hubungan dari masing-masingvariabel. Untuk melihat hubungan antara variabel independen (pengetahuan dan sikap) dengan variabel dependen (tindakan) maka dilakukan uji chisquare.
Tabel 1. Hubungan pengetahuan mahasiswa program profesi dengan tindakan terhadap pengendalian infeksi

\begin{tabular}{|c|c|c|c|c|c|c|c|}
\hline \multirow{3}{*}{$\begin{array}{l}\text { Pengetahuan tentang } \\
\text { pengendalian infeksi }\end{array}$} & \multicolumn{4}{|c|}{$\begin{array}{c}\text { Tidakan terhadap } \\
\text { pengendalian Infeksi }\end{array}$} & \multirow{2}{*}{\multicolumn{2}{|c|}{ Total }} & \multirow{3}{*}{ PValue } \\
\hline & \multicolumn{2}{|c|}{ Baik } & \multicolumn{2}{|c|}{ Buruk } & & & \\
\hline & $n$ & $\%$ & $n$ & $\%$ & $n$ & $\%$ & \\
\hline Tinggi & 33 & $80,5 \%$ & 8 & $19,5 \%$ & 41 & $100 \%$ & \\
\hline Rendah & 4 & $20 \%$ & 16 & $80 \%$ & 20 & $100 \%$ & 0,0005 \\
\hline Total & 37 & $60,7 \%$ & 24 & $39,3 \%$ & 61 & $100 \%$ & \\
\hline
\end{tabular}

Dari tabel di atas, hasil tabulasi silang menunjukkan bahwa persentase tertinggi yaitu $80,5 \%$ responden memiliki pengetahuan yang tinggi juga memiliki tindakan yang baik terhadap pengendalian infeksi. Hasil analisis dengan menggunakan chisquare menunjukkan terdapat hubungan yang bermakna antara pengetahuan dengan tindakan mahasiswa program profesi dokter gigi terhadap pengendalian infeksi $(\mathrm{p}<0,05)$.

Tabel 2. Hubungan sikap mahasiswa program profesi dengan tindakan terhadap pengendalian infeksi

\begin{tabular}{|c|c|c|c|c|c|c|c|}
\hline \multirow{3}{*}{$\begin{array}{c}\text { Sikap terhadap } \\
\text { pengendalian infeksi }\end{array}$} & \multicolumn{4}{|c|}{$\begin{array}{c}\text { Tidakan terhadap } \\
\text { pengendalian Infeksi }\end{array}$} & \multirow{2}{*}{\multicolumn{2}{|c|}{ Total }} & \multirow{3}{*}{ PValue } \\
\hline & \multicolumn{2}{|c|}{ Baik } & \multicolumn{2}{|c|}{ Buruk } & & & \\
\hline & $n$ & $\%$ & $n$ & $\%$ & $n$ & $\%$ & \\
\hline Positif & 30 & $71,4 \%$ & 12 & $28,6 \%$ & 42 & $100 \%$ & \\
\hline Negatif & 7 & $36,8 \%$ & 12 & $63.2 \%$ & 20 & $100 \%$ & 0,023 \\
\hline Total & 37 & $60,7 \%$ & 24 & $39,3 \%$ & 61 & $100 \%$ & \\
\hline
\end{tabular}

Dari tabel di atas, hasil tabulasi silang menunjukkan bahwa persentase tertinggi yaitu $71,4 \%$ responden memiliki sikap positif juga memiliki tindakan yang baik terhadap pengendalian infeksi. Hasil analisis dengan menggunakan chi-square menunjukkan terdapat hubungan yang bermakna antara sikap dengan tindakan mahasiswa program profesi dokter gigi terhadap pengendalian infeksi $(p<0,05)$. 


\section{HASIL DAN PEMBAHASAN}

Hasil penelitian pada gambar 6 menunjukkan bahwa sebagian besar pengetahuan responden mengenai pengendalian infeksi sudah baik sebanyak 41 orang $(67,2 \%)$ karena responden sama- sama mendapatkan pengetahuan tentang pengendalian infeksi pada masa preklinik. Pengetahuan merupakan faktor penting dan berpengaruh terhadap seseorang atau kelompok untuk bertindak, dimana pengetahuan merupakan hasil dari tahu dan ini terjadi setelah orang melakukan pengindraan terhadap suatu objek tertentu7. Pengetahuan responden rendah mengenai tujuan utama mencuci tangan sebanyak 74\%. Mencuci tangan adalah elemen penting dalam mencegah penularan penyakit. Tujuan utama mencuci tangan adalah membersihkan mikroba yang dapat mentransmisikan penyakit. Kulit manusia mengandung 2 tipe mikroba yaitu tarnsien dan residen. Mikroba residen adalah mikroba yang bertempat tinggal di lapisan lebih dalam kulit, sehingga dia hanya tidak sulit dibuang dibanding flora transien namun juga kurang beruhubungan dengan transmisi penyakit. Mikroba transien berada di lapisan luar kulit sehingga mudah untuk ditransmisikan melalui kontak langsung maupun tidak langsung dalam praktik kedokteran gigi ${ }^{15}$.

\section{SIMPULAN}

Berdasarkan penelitian yang dilakukan disimpulkan status gizi berdasarkan klasifikasi WHO-NCHS 2000 pada anak usia 13-15 tahun di SMPN 5 Kota Padang yaitu lebih dari $75 \%$ jumlah seluruh responden termasuk dalam kategori normaloverweight. Status persistensi gigi sulung pada pada anak usia 13-15 tahun di SMPN 5 Kota Padang yaitu lebih dari $25 \%$ jumlah seluruh responden memiliki gigi sulung yang persistensi. Terdapat 45 kasus gigi sulung yang persistensi pada 24 responden dan gigi kaninus memiliki presentase tertinggi gigi yang mengalami persistensi. Tidak adanya hubungan yang bermakna antara status gizi dengan persistensi gigi sulung pada anak usia 13-15 tahun di SMPN 5 Kota Padang.

Responden yang salah menjawab waktu mencuci baju pelindung adalah $54 \%$, dimana baju pelindung/ jas koas harus dicuci setiap hari karena percikan atau semprotan dapat terjadi selama prosedur dental. Sebanyak 64\% responden menjawab salah mengenai lama penggunaan masker. Apabila prosedur perawatan lebih dari 25-30 menit, maka masker dapat diganti dengan yang baru. Masker akan kehilangan kualitas perlindungannya jika basah ${ }^{11}$. Sebanyak $54 \%$ responden menjawab salah mengenai kode warna 
kantung untuk limbah infeksius. Kode warna untuk limbah layanan kesehatan terdiri dari kuning untuk limbah infeksius, kuning berlabel untuk benda tajam, cokelat untuk limbah bahan kimia dan sediaan farmasi, hitam untuk limbah layanan masyarakat ${ }^{16}$. Responden yang salah menjawab tentang bahan yang digunakan untuk membersihkan tumpahan darah dan bahan infeksius adalah 23\%. Bahan yang digunakan untuk membersihkan tumpahan darah dan bahan infeksius adalah sterilan, sterilan merupakan tipe antimikroba yang membunuh (menginaktivasi secara irreversibel) semua bakteri, fungi, dan virus termasuk spora. Hasil penelitian pada Gambar 2 secara keseluruhan responden mempunyai sikap positif sebanyak 42 orang $(68,9 \%)$. Tetapi sikap tersebut belum menjamin bahwa mahasiswa akan berprilaku atau bertindak dengan baik terhadap pengendalian infeksi. Sikap positif yang dimiliki responden disebabkan dalam menjawab pertanyaan selalu menjawab hal- hal yang baik saja, karena sikap merupakan respon yang masih tertutup dan tidak tampak dalam keadaan nyata, sehingga meskipun responden sangat setuju terhadap pengendalian infeksi belum tentu responden bertindak sesuai dengan sikapnya ${ }^{10}$.
Sikap responden negatif terhadap mencuci tangan kembali ketika mengganti sarung tangan pada saat melakukan tindakan sebanyak 10 orang (16\%), hal ini disebabkan karna responden berasumsi bahwa kondisi tangan tetap bersih apabila tidak menyentuh apapun saat melakukan pergantian sarung tangan pada saat prosedur tindakan. Menurut teori yang dikemukakan oleh sardjono tahun 2012, tangan di kategorikan kotor bila terkontaminasi cairan tubuh, kontak langsung dengan individu pasien, setelah kontak dengan permukaan dalam ruang praktik termasuk peralatan, gigi palsu, cetakan gips dan termasuk terkena serbuk/powder dari sarung tangan ${ }^{11}$. Sebanyak $36 \%$ responden menunjukkan sikap negatif terhadap fungsi cuci tangan yang dapat digantikan dengan pemakaian sarung tangan. Kebersihan tangan merupakan salah satu hal yang paling penting dalam pengendalian infeksi karena tangan merupakan tempat dari penularan mikroorganisme patogen ${ }^{17}$.

Tenaga pelayanan kesehatan gigi dan mulut harus melakukan kebersihan tangan dengan menggunakan sabun dan air mengalir jika tangan terlihat kotor, lamanya mencuci tangan 40-60 detik. Jika tangan tidak tampak kotor lakukan kebersihan tangan dengan cara gosok tangan dengan handscrub/cairan 
berbasis alkohol, lamanya 20-30 $\operatorname{detik}^{11}$. Sebanyak $24 \%$ responden menunjukkan sikap negatif terhadap pernyataan bahwa pengelolaan limbah medis cukup diketahui petugas yang menangani limbah medis. Pengelolaan limbah layanan kesehatan secara efektif adalah dengan pemilahan (segregasi) dan identifiksi limbah, Pemilahan merupakan tanggung jawab yang dibebankan pada produsen limbah (tenaga kesehatan) dan harus dilakukan sedekat mungkin dengan tempat dihasilkannya limbah ${ }^{16}$. Sebanyak $34 \%$ responden setuju terhadap sterilisasi area kerja hanya dilakukan setelah tindakan, hal ini disebabkan karena responden berasumsi bahwa area kerja dapat langsung digunakan karena sudah di bersihkan oleh pengguna sebelumnya. Walaupun demikian sterilisasi area kerja harus dilakukan sebelum dan setelah tindakan agar area kerja dalam kondisi steril saat digunakan dan tidak terjadi penyebaran mikroorganisme secara tidak langsung masuk ke dalam tubuh melalui media atau objek perantara yang terkontaminasi membawa berbagai macam mikroorganisme patogen yang berasal dari darah dan saliva pasien ${ }^{18}$.

Hasil penelitian pada Gambar 3 sebagian besar responden memiliki tindakan yang baik yaitu 37 orang
$(60,7 \%)$. Berdasarkan pengamatan yang dilakukan peneliti, hal ini dikarenakan adanya faktor- faktor yang mempengaruhi seperti responden cendrung terburuburu karena akan memberikan tindakan pada pasien dalam rentang waktu yang singkat sehingga kurang cermat dalam mempersiapkan peralatan secara optimal.

Tindakan yang salah terhadap pengendalian infeksi yaitu menggunakan kaca mata pelindung selama prosedur tindakan sebanyak $84 \%$, hal ini dikarenakan mahalnya harga kaca mata pelindung dan kurangnya kenyamanan dalam pemakaiannya. Tenaga pelayanan kesehatan gigi wajib menggunakan kacamata pelindung untuk menghindari kemungkinan infeksi pada konjungtiva akibat kontaminasi aerosol, percikan saliva dan darah. Kacamata ini harus di dekontaminasi dengan air dan sabun kemudian di disinfeksi setiap kali berganti pasien ${ }^{11}$. Sebanyak $93 \%$ responden tidak mengganti masker setelah 25-30 menit, disebabkan karena pengetahuan responden tentang mengganti masker setelah 2530 menit juga rendah. Sebagian besar responden hanya mengganti masker setiap kali berganti pasien walaupun lama prosedur tindakan lebih dari 30 menit. Seluruh responden $(100 \%)$ 
tidak membuang masker dan sarung tangan ke kontainer kuning karena tidak tersedianya kontainer kuning di RSGMP Universitas Andalas, tetapi responden tetap membuangnya pada kotak limbah medis. Sebanyak $75 \%$ responden tidak menggunakan alat pelindung diri lengkap saat mencuci peralatan. Sebagian besar dari responden tidak menggunakan sarung tangan, hal ini disebabkan karena mencuci tangan dilakukan setelah selesai membersihkan peralatan, jadi responden merasa tidak perlu menggunakan sarung tangan saat mencuci peralatan. Penggunaan sarung tangan pada saat mencuci peralatan bertujuan untuk mengurangi resiko penyebaran mikroorganisme pada kulit dan resiko tertusuk peralatan tajam. Sebanyak $74 \%$ responden tidak mengganti alas kerja pada meja dental unit setiap pasien baru, hal ini disebabkan karena sebagian besar responden hanya memiliki 1 buah alas kerja dan alas kerja yang di gunakan bukan alas kerja sekali pakai/disposible. Alas kerja/linen harus diganti setiap pasien baru karena dapat terkontaminasi dengan darah, cairan tubuh atau bahan infeksius lainnya. Tabel 6 menunjukkan frekuensi analisis antarapengetahuan dengan tindakan didominasi oleh pengetahaun yang tinggi dengan tindakan yang baik yaitu sebanyak 33 orang $(60,5 \%)$ dan adanya korelasi antara pengetahuan dengan tindakan terhadap pengendalian infeksi. Tabel 1 juga menunjukkan uji chi-square $(\mathrm{p}=$ $0.0005<\alpha=0.05)$ menunjukkan bahwa terdapat hubungan yang bermakna antara pengetahuan dengan tindakan. Hubungan yang terjadi bersifat searah yang berarti semakin tinggi pengetahuan yang dimiliki seseorang maka semakin tinggi juga tindakan terhadap pengendalian infeksi. Demikian sebaliknya semakin rendah pengetahuan yang dimiliki seseorang maka semakin rendah pula tindakannya. Hasil ini sejalan dengan penelitian Hidayat pada tahun 2016 di Semarang yang membuktikan ada hubungan bermakna antara pengetahuan dengan tindakan dokkter gigi dalam upaya pencegahan penyakit menular dengan nilai significancy $0.041(\mathrm{p}<0.05)$.

Hal sama juga dibuktikan oleh penelitian Rinendy pada tahun 2012 yang membuktikan bahwa terdapat hubungan antara pengetahuan dengan tindakan terhadap penyakit menular dengan nilai significancy 0.018 (p < 0.05). Hal tersebut juga membuktikan teori bahwa pengetahuan merupakan domain penting dan faktor awal seseorang untuk berprilaku. Pengetahuan sangat penting dalam mendasari terbentuknya tindakan 
karena suatu prilaku dibentuk dari pengetahuan sehingga pengetahuan baru akan menimbulkan tanggapan batin dalam bentuk sikap dan akan timbul tanggapan lebih jauh berupa tindakan. Pengetahuan yang baik tentang pengendalian infeksi yang dimiliki mahasiswa profesi dokter gigi dapat menentukan tindakan yang tepat dalam upaya pencegah dan pengendalian infeksi ${ }^{10}$.

Tabel 2 menunjukkan frekuensi analisis antara sikap dengan tindakan didominasi oleh sikap yang positif dengan tindakan yang baik yaitu sebanyak 30 orang $(71,4 \% \%)$ dan adanya korelasi antara sikap dengan tindakan terhadap pengendalian infeksi. Tabel 2 juga menunjukkan uji chisquare $(\mathrm{p}=0.023<\alpha=0.05)$ menunjukkan bahwa terdapat hubungan yang bermakna antara sikap dengan tindakan. Hubungan yang terjadi bersifat searah yang berarti semakin positif sikap yang dimiliki seseorang maka semakin baik juga tindakan terhadap pengendalian infeksi. Demikian sebaliknya semakin negatif sikap yang dimiliki seseorang maka semakin buruk pula tindakannya. Hasil penelitian ini mendukung penelitian yang dilakukan oleh Rinendy pada tahun 2012 bahwa terdapat hubungan yang bermakna antara sikap dengan tindakan terhadap penyakit menular dengan nilai significancy $0.010(\mathrm{p}<0.05)$.

Hal ini juga membuktikan teori bahwa sikap merupakan domain dalam membentuk prilaku. Sikap itu merupakan kesiapan atau kesediaan untuk bertindak, sikap yang positif tentang pengendalian infeksi yang dimiliki mahasiswa profesi dokter gigi dapat mempengaruhi tindakan yang tepat dalam upaya pencegah dan pengendalian infeksi ${ }^{10}$.

1. Sebagian besar mahasiswa program profesi dokter gigi memiliki pengetahuan yang tinggi terhadap pengendalian infeksi.

2. Sebagian besar mahasiswa program profesi dokter gigi memiliki sikap yang positif terhadap pengendalian infeksi.

3. Sebagian besar mahasiswa program profesi dokter gigi memiliki tindakan yang baik terhadap pengendalian infeksi.

4. Hasil penelitian keseluruhan mengenai hubungan pengetahuan dengan tindakan mahasiswa program profesi dokter gigi diperoleh hasil analisis yang menunjukan terdapat hubungan yang bermakna antara pengetahuan terhadap tindakan pengendalian infeksi.

5. Hasil penelitian keseluruhan mengenai hubungan pengetahuan 
dengan tindakan mahasiswa program profesi dokter gigi diperoleh hasil analisis yang menunjukan terdapat hubungan yang bermakna antara sikap terhadap tindakan pengendalian infeksi.

\section{SIMPULAN}

Berdasarkan penelitian yang dilakukan disimpulkan status gizi berdasarkan klasifikasi WHO-NCHS 2000 pada anak usia 13-15 tahun di SMPN 5 Kota Padang yaitu lebih dari $75 \%$ jumlah seluruh responden termasuk dalam kategori normaloverweight. Status persistensi gigi sulung pada pada anak usia 13-15 tahun di SMPN 5 Kota Padang yaitu lebih dari $25 \%$ jumlah seluruh responden memiliki gigi sulung yang persistensi. Terdapat 45 kasus gigi sulung yang persistensi pada 24 responden dan gigi kaninus memiliki presentase tertinggi gigi yang mengalami persistensi. Tidak adanya hubungan yang bermakna antara status gizi dengan persistensi gigi sulung pada anak usia 13- 15 tahun di SMPN 5 Kota Padang.

\section{KEPUSTAKAAN}

1. Pedersen, Gordon W. Buku Ajar Praktis Bedah Mulut (Oral Surgery)/Gordon W.Pedersen;
editor,Lilian Yuwono. EGC:

Jakarta. 2012.

2. Departemen Kesehatan RI. Laporan Hasil Riset Kesehatan Dasar (Riskesdas) Nasional. Badan Penelitian dan Pengembangan Kesehatan Dasar Depkes RI. Jakarta. 2013.

3. Kepel,BJ. Tindakan pencegahan dan pengendalian infeksi pada perawatan periodonsia di rumah sakit gigi dan mulut Unsrat. Jurnal e-gigi. 2015: 3(2).

4. Wibowo dkk, 2009. Proteksi Dokter Gigi Sebagai Pemutus Rantai Infeksi Silang. Jurnal PDGI. Vol. 58, No. 2; Hal.6-9.

5. Arias, KM. Infestigasi dan pengendalian wabah di fasilitas pelayanan kesehatan. EGC: Jakarta. 2010, pp. 113-4. A vailable from URL: https://books.google.co.id/books?i sbn:97904 4009X.

6. Shara, AC. Hubungan antara pengetahuan terhadap motivasi dokter gigi muda dalam control infeksi. Media Dental Intelektual Jurnal. 2014: Vol.2 ed.1st..

7. Center for Disease Control and Prevention. Guidline for Infection in Dental Health- Care Settings. MMWR 2003; 52. 2003

8. The Dental Council. Code of practice relating to infection 
control in dentistry. 57 Merrioj

Square, Dublin 2, 2005, pp. 2-29.

Available

from:URL:http://www.dentalcoun

cil.ie/files/I nfection_Conntrol.pdf.

Accessed Desember 5, 2016.

9. Lugito, M. Kontrol Infeksi dan keselamatan kerja dalam praktek kedokteran gigi. Jurnal PDGI. 2013; 62(1): 24-30.

10. Notoatmodjo. Pendidikan dan Perilaku Kesehatan. PT. Rineka Cipta: Jakarta. 2003.

11. Sardjono B, dkk. Standar pencegahan dan pengendalian infeksi pelayanan kesehatan gigi dan mulut di fasilitas pelayanan kesehatan. Kementrian Kesehatan RI; 2012. Available from URL:http://pdgi.or.id/wpcontent/uploads/2015/04/PPIGilut. pdf.

12. Hidayat dkk, Hubungan Antara Pengetahuan dan Tindakan Dokter Gigi dalam Upaya Pencegahan Penyakit Menular. Odonto dental journal. 2016: 3(2).

13. Susila dan suyanto. Metodologi Penelitian Cross Sectional Kedokteran dan kesehatan. Bossscript: Klaten. 2015.

14. Saryono A. Metode Penelitian Kualitatif dan Kuantitatif dalam Bidang Kesehatan. nuhamedika: Yogyakarta. 2013.
15. Cole, M., Breaking The Chain of Infection. Article in Nursing and Residential care. 2012; 14(6): 255291.

16. Pruss A, Giroult E, Rushbrook P. Pengelolaan Aman Limbah Layanan Kesehatan. EGC: Jakarta. 2005.

17. Kohn W., dkk. Guidelines for Infection Control in Dental Health Settings. 2003.

18. Tietjen, dkk. Panduan Pencegahan Infeksi Untuk Fasilitas Pelayanan Kesehatan dengan Sumber daya Terbatas. Yayasan Bina Pustaka. 2010. 